\title{
Role of daily light period in the depth distribution of Zostera marina (eelgrass)
}

\author{
William C. Dennison* \& Randall S. Alberte \\ Barnes Laboratory, The University of Chicago, 5630 S. Ingleside Ave., Chicago, Illinois 60637, USA
}

\begin{abstract}
Photosynthesis, biomass and growth characteristics of the temperate seagrass, Zostera marina L. (eelgrass), were examined in a meadow in Great Harbor, Woods Hole, Massachusetts during June and August, 1982. Underwater lamps and light shading screens were placed at shallow $(1.3 \mathrm{~m})$ and deep $(5.5 \mathrm{~m})$ stations to lengthen and shorten daily light periods. The portion of the day $\left(\mathrm{H}_{\text {sal }}\right)$ that light intensities saturated $Z$. marina photosynthesis was lengthened by 4 to $6 \mathrm{~h}$ and shortened by 3 to $5 \mathrm{~h}$. Photosynthesis vs irradiance relations, leaf chlorophyll content, photosynthetic unit size and density, shoot size, specific leaf area, leaf biomass, and production rates were determined at the end of $30 \mathrm{~d}$ experiments. Cellular photosynthetic adjustment (photosynthesis vs irradiance relationships, chlorophyll and photosynthetic unit characteristics) to the $\mathrm{H}_{\text {sat }}$ manipulations occurred only in June, however biomass and growth adjustments occurred both in June and August. Photosynthesis and respiration rates, and $\mathrm{H}_{\text {sat }}$ regimes, were used to calculate daily leaf carbon balances. Daily carbon balance was an accurate predictor of plant survival. Plant responses to manipulations indicate that growth is light limited for eelgrass growing near the deep edge of the meadow, and that these plants appear to be living near the minimum light regime for growth and survival $\left(\mathrm{H}_{\text {sat }}=6\right.$ to $\left.8 \mathrm{~h}\right)$. Maximum depth distribution of this species appears to be controlled principally by daily light periods.
\end{abstract}

\section{INTRODUCTION}

Zostera marina L., a prolific temperate seagrass, often grows within a distinct band extending from the intertidal to water depths ranging from several to tens of meters. Along this natural depth distribution is a gradient in light availability. Plants growing in shallow water are exposed to nearly full sunlight, while plants at depth receive only a small fraction of this light due to attenuation by the water column. Photosynthetic and growth responses of eelgrass to these natural light gradients have been described (Wiginton \& McMillan 1979, Mazzella et al. 1981, Dennison \& Alberte 1982). Several studies have extended these types of investigations to examine the influence of light on eelgrass growth using in situ manipulations of photosynthetic photon flux density (PPFD) regimes (Burkholder \& Doheny 1968, Backman \& Barilotti 1976, Dennison \& Alberte 1982). In general, decreased PPFD

\footnotetext{
- Present address: Marine Sciences Research Center, State University of New York, Stony Brook, New York 11794, USA
}

resulted in decreased biomass and growth, but increased PPFD had no significant effect on these parameters.

It was found that PPFD manipulations conducted at shallow $(1.3 \mathrm{~m})$ and deep $(5.5 \mathrm{~m})$ stations in an eelgrass meadow in Great Harbor, Woods Hole, Massachusetts brought about a growth response only when changes in PPFD were accompanied by significant changes in daily light periods (Dennison \& Alberte 1982). These daily light periods were defined in terms of eelgrass photosynthetic response: the daily period in which PPFD is equal to or exceeds the photosynthetic light saturation point for Zostera marina is defined as $\mathrm{H}_{\text {sat }}$ and the daily period in which PPFD is equal to or exceeds the photosynthetic light compensation point is defined as $\mathrm{H}_{\text {comp }}$ (Dennison \& Alberte 1982). Daily light periods $\left(\mathrm{H}_{\text {sat }}\right.$ and $\left.\mathrm{H}_{\text {comp }}\right)$ were manipulated in situ in the present study to test the hypothesis that daily light periods control the depth distribution, photosynthesis and productivity of eelgrass growing along a natural depth gradient. The $\mathrm{H}_{\text {sat }}$ concept was used in defining light regimes, although both $\mathrm{H}_{\text {sat }}$ and $\mathrm{H}_{\text {comp }}$ are important features of the light environment. 


\section{MATERIAL AND METHODS}

Study site. The study site was an eelgrass meadow located in Great Harbor near Woods Hole, Massachusetts $\left(40^{\circ} 31.5^{\prime} \mathrm{N} ; 70^{\circ} 40.5^{\prime} \mathrm{W}\right)$. Two stations were established near the shallow and deep edges of the meadow corresponding to locations previously investigated (see Dennison \& Alberte 1982). All sampling and field activities were conducted in the spring and summer of 1982 using SCUBA gear

In situ light manipulations. Lengthening the daily light periods in situ was accomplished with underwater lamps (300 W bulb encased in a cast bronze housing; Hubbel Inc., VA) which were buoyed $1 \mathrm{~m}$ above the eelgrass canopy at the shallow and deep stations. The $120 \mathrm{~V}$ system was connected with waterproof cable to a timer and outlet located $50 \mathrm{~m}$ from each station. The lamps provided approximately $200 \mu \mathrm{E} \mathrm{m}^{-2}$ $\mathrm{s}^{-1}$ from 0200 to $0800 \mathrm{~h}$ local time. Shortening the daily light periods in situ was accomplished with light shading screens which were also placed at both stations as in Dennison \& Alberte (1982). The screens, buoyed $1 \mathrm{~m}$ above the bottom, decreased ambient light intensities by $80 \%$ at the shallow station and $55 \%$ at the deep station to achieve reductions in $\mathrm{H}_{\text {sat }}$ of 2.9 to $4.7 \mathrm{~h}$. Regular cleaning removed detritus and algal and invertebrate growth from the lamps and shades.

Two $30 \mathrm{~d}$ experiments were conducted in June and August, 1982. One sample quadrat $\left(0.06 \mathrm{~m}^{2}\right)$ and 2 plexiglass corers $(15 \mathrm{~cm}$ diameter $\times 10 \mathrm{~cm}$ height) were placed in the sediments at each control, shade, and underwater lamp site. At the beginning of the experiments, all eelgrass shoots within the quadrats and corers were marked with a hole several millimeters above the bundle sheath for growth measurements.

Quantum flux and $H_{\text {sat }}$ measurements. In situ quantum flux measurements could be made only during visits to the field site, however hourly values of solar radiation (lys $\mathrm{h}^{-1}$ ) from above the water surface were also available (Eppley Laboratory, Newport, RI; Woods Hole Oceanographic Institution, Woods Hole, MA). Hence, underwater PPFD was measured during field excursions with a submersible, hand-held $4 \pi$ quantum sensor which measured photosynthetically active radiation (PAR $=400$ to $700 \mathrm{~nm}$ ) (Biospherical QS I-140) and these values compared with simultaneous readings of the pyrheliometer above the water surface. Simultaneous readings of the quantum sensor $\left(\mu \mathrm{E} \mathrm{m}^{-2}\right.$ $\mathrm{s}^{-1}$ ) and pyrheliometer (lys $\mathrm{h}^{-1}$ ) were performed on 50 days and averaged to empirically derive conversion factors. These factors converted not only langleys to quanta of photosynthetically active radiation, but converted above-water surface readings to underwater values taken at the top of the leaf canopy. It was determined that $20.9 \pm 1.0$ lys $\mathrm{h}^{-1}(\overline{\mathrm{X}} \pm \mathrm{SE}$ ) above the water surface corresponded to $1 \mu \mathrm{E} \mathrm{m}^{-2} \mathrm{~s}^{-1}$ at the shallow station, and that $5.5 \pm 0.3 \mathrm{lys} \mathrm{h}^{-1}(\overline{\mathrm{X}} \pm \mathrm{SE})=$ $1 \mu \mathrm{E} \mathrm{m}^{-2} \mathrm{~s}^{-1}$ at the deep station. By converting the hourly solar radiation values to estimates of in situ PPFD, diumal light curves could be constructed for each station. Either the hourly in situ light values were then integrated for daily quantum fluxes, or the length of the day that PPFD was $100 \mu \mathrm{E} \mathrm{m}^{-2} \mathrm{~s}^{-1}$ or greater was determined $\left(\mathrm{H}_{\mathrm{s}: \mathrm{t}}\right)$.

Plant material. Zostera marina shoots were collected from control and experimental sites at the completion of the $30 \mathrm{~d}$ light treatments. Plants within quadrats were clipped at the basal meristem, transported to the laboratory and measured within $24 \mathrm{~h}$ for leaf elongation. Plants in the plexiglass corers were removed with an intact sediment plug and placed in flowing seawater aquaria with artificial illumination $\left(130 \mu \mathrm{E} \mathrm{m}^{-2} \mathrm{~s}^{-1}\right.$, PAR). Single shoots were removed from the aquaria immediately prior to photosynthesis measurements. All physiological measurements were made within $32 \mathrm{~h}$ of collection; photosynthetic measurements were performed within $24 \mathrm{~h}$, followed by chlorophyll assessments. A time course analysis of photosynthetic activity showed no appreciable decline in activity over a $24 \mathrm{~h}$ period when plants were maintained in the laboratory aquaria. To insure uniform sampling, leaf segments for photosynthesis measurements were selected by locating the $30 \mathrm{~d}$ old scars from the syringe needle holes, and excising leaf tissue which emerged from the bundle sheath approximately $15 \mathrm{~d}$ after the initial marking. Little epiphyte biomass was observed on this leaf tissue, which had recently emerged from the bundle sheath.

Photosynthesis and respiration determinations. Three 2 cm leaf segments were placed in a Clark-type oxygen electrode chamber (Rank Brothers, England), with rapid mixing, for photosynthesis and respiration measurements (Dennison \& Alberte 1982). Ambient seawater temperatures $\left(20^{\circ} \mathrm{C}\right)$ were maintained for all photosynthesis and respiration determinations in both June and August experiments. Photosynthesis vs irradiance (P-I) relationships were determined using neutral density filters and a Kodak projector lamp to establish a range of light intensities. One P-I curve was constructed for each treatment by averaging values from 3 P-I curves in which 3 different plants from each treatment were used. The integrated P-I curves were formed by: (1) averaging the net photosynthetic rates at PPFDs $>150 \mu \mathrm{E} \mathrm{m} \mathrm{m}^{-2} \mathrm{~s}^{-1}$ to estimate light-saturated photosynthetic rates $\left(P_{\max }\right)_{i}(2)$ calculating a linear regression of the photosynthetic rates at PPFDs $<60 \mu \mathrm{E}$ $\mathrm{m}^{-2} \mathrm{~s}^{-1}$ forced to pass through the dark respiration point to estimate initial slope $(\alpha)_{i}(3)$ calculating the light saturation points from the intersections of $\alpha$ and 
Table 1. Average daily quantum flux at the top of the eelgrass leaf canopy during June and August 1982 experiments at the shallow and deep stations, and average daily light periods $\left(\mathrm{H}_{\text {sat }}\right)$ of light intensities equal to or exceeding the photosynthetic light saturation point for Zostera marina $\left(100 \mu \mathrm{E} \mathrm{m}^{-2} \mathrm{~s}^{-1}\right)$

\begin{tabular}{|c|c|c|c|c|}
\hline & \multicolumn{2}{|c|}{ Daily quantum flux $\left(\mathrm{E} \mathrm{m}^{-2} \mathrm{~d}^{-1}\right)$} & \multicolumn{2}{|c|}{ Daily light period $\left(\mathrm{H}_{\text {sat }}: \mathrm{h}\right)$} \\
\hline & June & August & June & August \\
\hline \multicolumn{5}{|l|}{ Shallow station } \\
\hline Lengthened light period & 34.8 & 34.7 & 16.7 & 16.9 \\
\hline Control & 31.7 & 30.9 & 12.8 & 12.1 \\
\hline Shortened light period & 6.3 & 6.2 & 8.1 & 7.5 \\
\hline \multicolumn{5}{|l|}{ Deep station } \\
\hline Lengthened light period & 12.2 & 11.6 & 14.1 & 13.3 \\
\hline Control & 8.2 & 8.0 & 9.0 & 8.8 \\
\hline Shortened light period & 3.7 & 3.6 & 5.8 & 5.9 \\
\hline
\end{tabular}

$\mathrm{P}_{\max }$ (4) calculating the light compensation points from the intersection of $\alpha$ and the ordinate. A comparison of linear regressions was used to determine statistical differences between $\alpha$ values, and $P_{\max }$ differences were tested by a 1-way ANOVA.

Carbon balance determinations. Gross daily photosynthetic rates were calculated by adding net $\mathrm{P}_{\max }$ to the absolute value of the respiration rates, and then multiplying this sum by the average $\mathrm{H}_{\text {sat }}$. This simple model of daily photosynthesis did not incorporate leaf canopy shelf shading or photoadaptation within the leaf canopy. Daily respiration rates were estimated from dark respiration rates calculated for $24 \mathrm{~h}$ periods, assuming that dark rates were unchanged under photosynthetic conditions. The daily net photosynthetic rates represent gross photosynthetic rates minus respiration. A factor of $0.30 \times \mathrm{mg} \mathrm{C}=\mathrm{mg} \mathrm{O} \mathrm{O}_{2}$ was used to obtain carbon values from $\mathrm{O}_{2}$ measurements (McRoy \& McMillan 1977).

Photosynthetic unit characteristics. The photosynthetic unit (PSU) size based on the concentration of photosystem II reaction centers relative to total chlorophyll $(a+b)$, termed PSU-O $\mathrm{O}_{2}$, was determined. The PSU-O $\mathrm{O}_{2}$ size was calculated from Emerson and Arnold numbers (divided by 4) (Kursar \& Alberte 1983) obtained from the oxygen yield per flash of light pulsed at $200 \mathrm{~ms}$ intervals (Mishkind \& Mauzerall 1980, Dennison \& Alberte 1982). Chlorophyll $a$ and $b$ was extracted in $80 \%(\mathrm{~V} / \mathrm{v})$ acetone and quantified spectrophotometrically (Arnon 1949). Chlorophyll per leaf area was divided by the PSU $-\mathrm{O}_{2}$ size to obtain PSU density (Alberte et al. 1976).

Leaf biomass and production. Ten randomly selected shoots from each treatment were measured for leaf area (length $\times$ width) and dry weight $\left(80^{\circ} \mathrm{C}, 24 \mathrm{~h}\right)$. The scars from the syringe needle holes were located and leaf tissue which emerged from the bundle sheath prior to marking was separated from that which emerged subsequently. Shoot production and turnover times were determined from the ratio of leaf dry weight produced during the experiment to total leaf dry weight at the end of the experiment. Shoot density was determined at each station and the following parameters calculated from shoot size, shoot density and leaf elongation: leaf biomass $\mathrm{m}^{-2}$, relative leaf production, leaf production $\mathrm{m}^{-2}$, and leaf formation rates (see Dennison \& Alberte 1982).

Statistical analyses. Statistical comparisons of shallow and deep stations and comparisons of lengthened and shortened $\mathrm{H}_{\text {sat }}$ conditions with the respective control sites for photosynthesis, growth and biomass parameters were made with 1-way ANOVA and Scheffe's multiple comparison of means at the $p<0.05$ confidence level. Three replicates per treatment were used for photosynthetic characteristics and 10 replicates used for growth and biomass characteristics.

\section{RESULTS}

The average diurnal light curves for the June experiments are plotted for shallow (Fig. 1a) and deep (Fig. 1 b) stations. Integrations of these curves yielded daily PPFD about 4 times higher at the shallow station (31 E $\left.\mathrm{m}^{-2} \mathrm{~d}^{-1}\right)$ than at the deep station $\left(8 \mathrm{E} \mathrm{m}^{-2} \mathrm{~d}^{-1}\right)$; these daily PPFDs were similar in June and August experiments (Table 1). The daily integrated PPFDs were variable, ranging from 4.3 to $50.2 \mathrm{E} \mathrm{m}^{-2} \mathrm{~d}^{-1}$ at the shallow station and 1.1 to $13.0 \mathrm{E} \mathrm{m}^{-2} \mathrm{~d}^{-1}$ at the deep station. Instantaneous PPFD was also variable with maximum values at the shallow station of $1640 \mu \mathrm{E} \mathrm{m}^{-2}$ $\mathrm{s}^{-1}$ and maximum values at the deep station of $435 \mu \mathrm{E}$ $\mathrm{m}^{-2} \mathrm{~s}^{-1}$. The underwater lamps increased daily PPFDs 

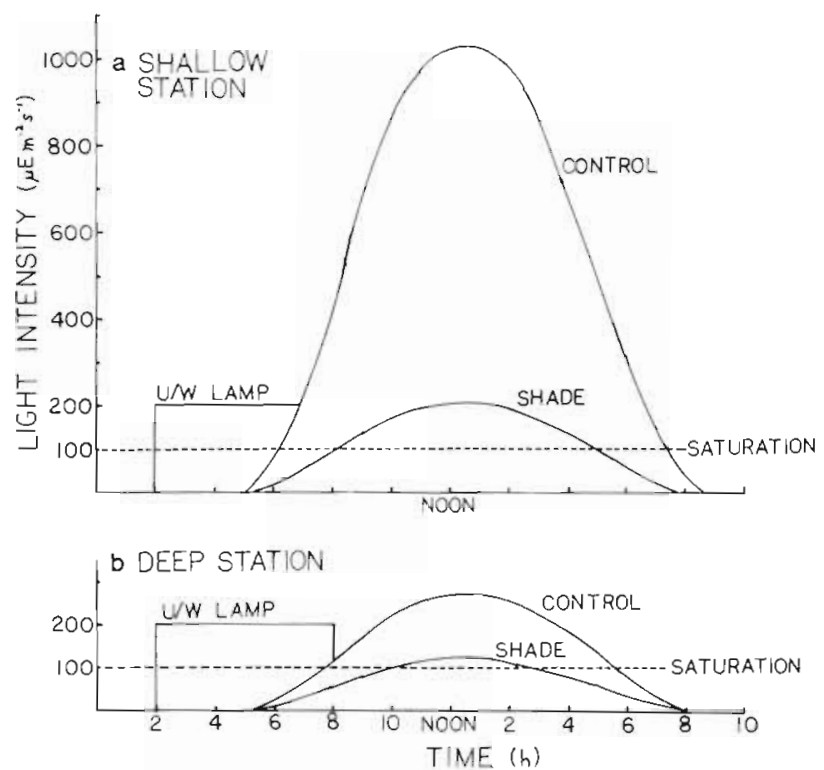

Fig. 1. Average diurnal light curves at top of eelgrass leaf canopy at shallow (a) and deep (b) stations for June, with control and shade treatments indicated. Underwater (U/W) lamps were turned on at 0200 and off at $0800 \mathrm{~h}$, local time only 10 to $20 \%$ at the shallow station, but 45 to $49 \%$ at the deep station. The shade screens resulted in an $80 \%$ reduction in PPFD at the shallow station, and a $55 \%$ reduction at the deep station.

The average periods of $H_{\text {sat }}$ were 12.8 and $12.1 \mathrm{~h}$ at the shallow station, and 9.0 and $8.8 \mathrm{~h}$ at the deep station in June and August, respectively (Table 1). The underwater lamps lengthened $\mathrm{H}_{\text {sat }}$ by 3.4 to $4.6 \mathrm{~h}$, and shade screens shortened $\mathrm{H}_{\text {sat }}$ by 2.9 to $4.7 \mathrm{~h}$. Although shade screens reduced daily quantum flux by $80 \%$ at the shallow station and $55 \%$ at the deep station, the shortening of $\mathrm{H}_{\text {sat }}$ was $40 \%$ of controls at both stations. The $\mathrm{H}_{\text {sat }}$ values determined for shallow and deep stations in 1981 (Dennison \& Alberte 1982) were about 2 h shorter than those determined here (Table 1), principally because fewer light measurements were made in the earlier study and less accurate conversion factors were derived.

The growth, biomass and photosynthetic features of the eelgrass plants under control and manipulated $\mathrm{H}_{\text {sat }}$ conditions are described below for the June and August experiments.
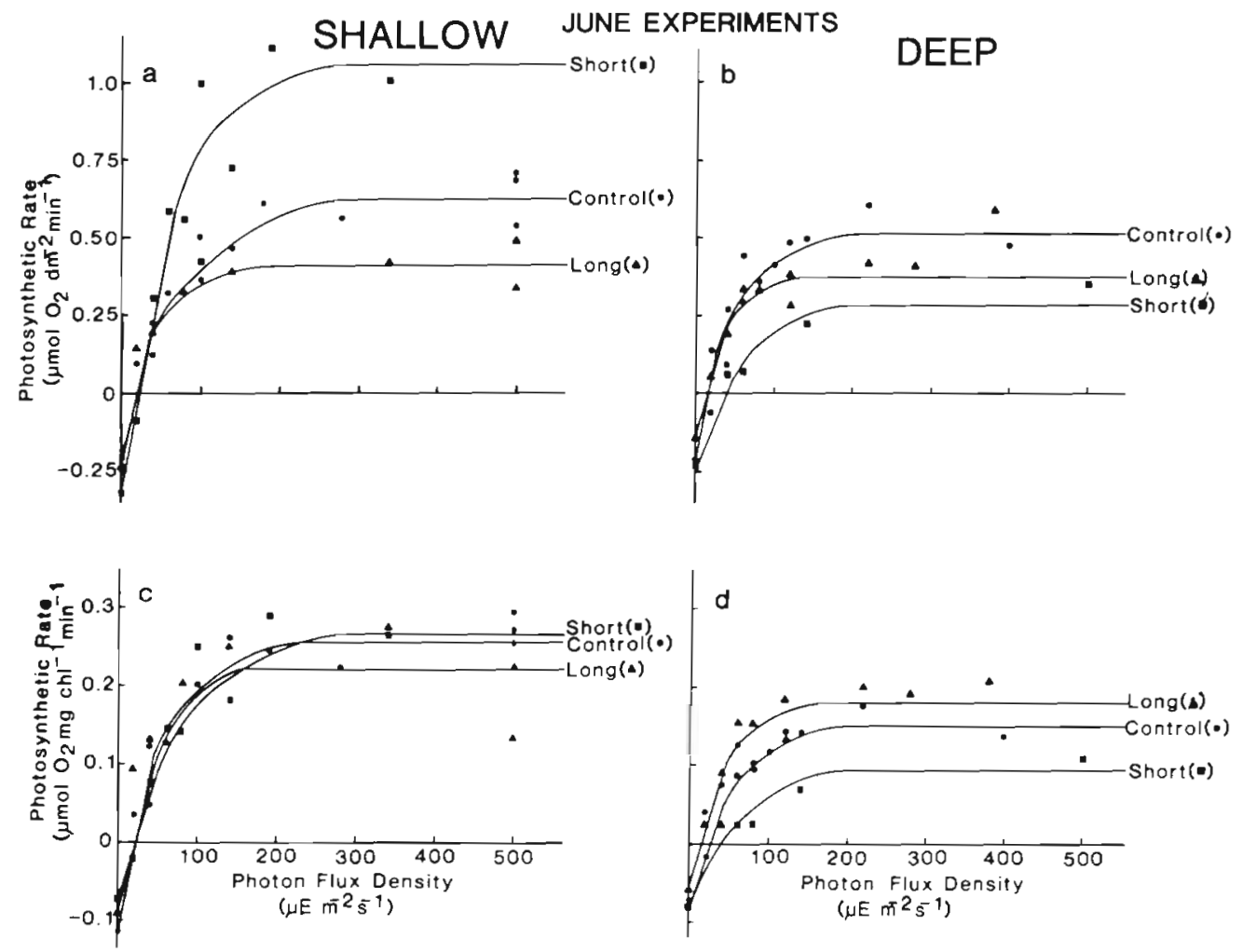

Fig. 2. Zostera marina. Photosynthesis-irradiance curves for shallow and deep station. Leaf tissue collected from control, lengthened (long) and shortened (short) daily light period sites at the completion of June experiments. Net photosynthesis expressed as a function of leaf area $(a, b)$ and as a function of chlorophyll (c, d) 
Table 2. June experiments. Photosynthetic, biomass, and growth parameters of Zostera marina for control and manipulation sites at shallow and deep stations

\begin{tabular}{|c|c|c|c|c|c|c|}
\hline \multirow[t]{2}{*}{ Parameter } & \multicolumn{3}{|c|}{ Shallow station } & \multicolumn{3}{|c|}{ Deep station } \\
\hline & $\begin{array}{l}\text { Lengthened } \\
\qquad \mathrm{H}_{\text {sat }}\end{array}$ & Control & $\begin{array}{l}\text { Shortened } \\
\mathrm{H}_{\text {sal }}\end{array}$ & $\begin{array}{l}\text { Lengthened } \\
\qquad \mathrm{H}_{\text {sát }}\end{array}$ & Control & $\begin{array}{c}\text { Shortened } \\
\mathrm{H}_{\text {sat }}\end{array}$ \\
\hline $\begin{array}{l}\mathrm{P}_{\max } \text { (net) } \\
\quad \mu \mathrm{mol} \mathrm{O} \mathrm{dm}_{2}^{-2} \mathrm{~min}^{-1} \\
\mu \mathrm{mol} \mathrm{O}_{2} \mathrm{mg} \mathrm{chl}^{-1} \mathrm{~min}^{-1}\end{array}$ & $\begin{array}{l}0.41^{\mathrm{a}} \\
0.22^{\mathrm{a}}\end{array}$ & $\begin{array}{l}0.62^{\mathrm{b}} \\
0.26^{\mathrm{a}}\end{array}$ & $\begin{array}{l}1.06^{\mathrm{c}} \\
0.27^{\mathrm{a}}\end{array}$ & $\begin{array}{l}0.38^{\mathrm{a}} \\
0.18^{\mathrm{b}}\end{array}$ & $\begin{array}{l}0.52^{b} \\
0.15^{b}\end{array}$ & $\begin{array}{l}0.29^{\mathrm{a}} \\
0.10^{\mathrm{c}}\end{array}$ \\
\hline $\begin{array}{l}\text { Leaf chlorophyll content } \\
\text { mg chl dm }{ }^{-2} \\
\text { chlorophyll } a / b\end{array}$ & $\begin{array}{l}2.1^{\mathrm{a}} \\
2.2^{\mathrm{a}}\end{array}$ & $\begin{array}{l}2.4^{\mathrm{a}} \\
2.2^{\mathrm{a}}\end{array}$ & $\begin{array}{l}4.6^{\mathrm{b}} \\
2.0^{\mathrm{a}}\end{array}$ & $\begin{array}{l}3.0^{\mathrm{c}} \\
2.1^{\mathrm{a}}\end{array}$ & $\begin{array}{l}3.2^{c} \\
2.1^{\mathrm{a}}\end{array}$ & $\begin{array}{l}3.0^{\mathrm{c}} \\
2.0^{\mathrm{a}}\end{array}$ \\
\hline $\begin{array}{l}\text { Photosynthetic unit size } \\
\text { PSU-O }\end{array}$ & $790^{\mathrm{a}}$ & $450^{b}$ & $780^{\mathrm{a}}$ & $1330^{c}$ & $820^{\mathrm{b}}$ & $1330^{c}$ \\
\hline $\begin{array}{l}\text { Photosynthetic unit density } \\
\text { nmol PSU }-\mathrm{O}_{2} \mathrm{dm}^{-2}\end{array}$ & $2.9^{\mathrm{a}}$ & $6.2^{\mathrm{b}}$ & $6.6^{\mathrm{b}}$ & $2.6^{\mathrm{a}}$ & $4.6^{\mathrm{a}}$ & $2.4^{\mathrm{a}}$ \\
\hline $\begin{array}{l}\text { Shoot size } \\
\text { g (dry) shoot }{ }^{-1}\end{array}$ & $0.23^{\mathrm{a}}$ & $0.24^{\mathrm{a}}$ & $0.12^{\mathrm{a}}$ & $0.40^{\mathrm{a}}$ & $0.37^{\mathrm{a}}$ & $0.21^{\mathrm{a}}$ \\
\hline $\begin{array}{l}\text { Leaf biomass } \\
\qquad g(d r y) m^{-2}\end{array}$ & $160^{\mathrm{a}}$ & $190^{a}$ & $90^{\mathrm{b}}$ & $90^{b}$ & $80^{\mathrm{b}}$ & $40^{c}$ \\
\hline $\begin{array}{l}\text { Specific leaf area } \\
\text { (leaf tissue produced during } \\
\text { experiments) } \mathrm{dm}^{2} \mathrm{~g}(\mathrm{dry})^{-1}\end{array}$ & $1.8^{\mathrm{a}}$ & $2.0^{\mathrm{a}}$ & $2.8^{\mathrm{b}}$ & $2.0^{\mathrm{a}}$ & $1.9^{\mathrm{a}}$ & $2.7^{b}$ \\
\hline $\begin{array}{l}\text { Relative leaf production rate } \\
\mathrm{mg}(\mathrm{d} r \mathrm{y}) \mathrm{g}(\mathrm{d} r \mathrm{y})^{-1} \mathrm{~d}^{-1}\end{array}$ & $17^{\mathrm{a}}$ & $17^{\mathrm{a}}$ & $13^{b}$ & $18^{\mathrm{a}}$ & $18^{\mathrm{a}}$ & $13^{b}$ \\
\hline $\begin{array}{l}\text { Leaf production rate } \\
\mathrm{g}(\mathrm{d} r \mathrm{y}) \mathrm{m}^{-2} \mathrm{~d}^{-1}\end{array}$ & $3.1^{\mathrm{a}}$ & $3.4^{\mathrm{a}}$ & $1.7^{b}$ & $2.2^{\mathrm{b}}$ & $1.9^{b}$ & $0.9^{c}$ \\
\hline $\begin{array}{l}\text { Leaf formation rate } \\
\qquad d\end{array}$ & $13^{\mathrm{a}}$ & $14^{\mathrm{a}}$ & $15^{\mathrm{a}}$ & $16^{\mathrm{a}}$ & $19^{a}$ & $35^{b}$ \\
\hline
\end{tabular}

\section{June experiments}

\section{Photosynthetic characteristics}

The P-I relations were examined with net photosynthesis expressed on both a leaf area basis (Fig. 2a, b) and a chlorophyll basis (Fig. 2c, d). The light compensation point for Zostera marina photosynthesis was 15 to $25 \mu \mathrm{E} \mathrm{m}^{-2} \mathrm{~s}^{-1}$, while the light saturation point was 65 to $120 \mu \mathrm{E} \mathrm{m}^{-2} \mathrm{~s}^{-1}$. The initial slopes of the P-I curves were compared by testing for significant differences between initial slope regressions; these did not vary between stations or in any of the treatments ( $p$ $<0.05$ ), and the mean was $4.4 \mathrm{nmol} \mathrm{O}_{2} \mathrm{mg} \mathrm{chl}^{-1}$

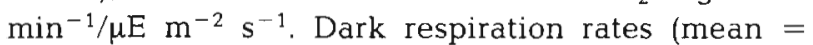
$0.08 \mu \mathrm{mol} \mathrm{O} \mathrm{O}_{2} \mathrm{mg} \mathrm{chl}^{-1} \mathrm{~min}^{-1}$ ) were also not significantly different beween stations or in any of the treatments $(\mathrm{p}<0.05)$.

The most responsive feature of the P-I relationship to the $\mathrm{H}_{\text {sat }}$ manipulations was $\mathrm{P}_{\max }$. At the shallow station, $P_{\max }$ of the shortened $\mathrm{H}_{\text {sat }}$ plants was nearly twice that of controls (Fig. 2a). This increase in photosynthetic activity was not observed when $\mathrm{P}_{\max }$ was expressed on a chlorophyll basis (Table 2, Fig. 2c), because the leaf chlorophyll content of shortened $\mathrm{H}_{\text {sat }}$ plants $(4.6 \mathrm{mg}$ chl $\mathrm{dm}^{-2}$ ) was about twice that of control plants $(2.4 \mathrm{mg}$ chl $\mathrm{dm}^{-2}$; Table 2). The increased leaf chlorophyll content was obvious even in the field, as the eelgrass shoots growing under the shallow station shade had leaves which were much darker green in appearance than leaves of surrounding shoots. Lengthened $\mathrm{H}_{\text {sat }}$ plants showed a $33 \%$ reduction in $\mathrm{P}_{\max } \mathrm{dm}^{-2}$ but no significant change on a chlorophyll basis. Leaf chiorophyll content and chlorophyll $a / b$ ratios were not affected.

The PSU-O $\mathrm{O}_{2}$ sizes in plants from the shallow station were almost 2 -fold greater in both shortened 780 light harvesting pigments/reaction center) and lengthened (790) $\mathrm{H}_{\text {sat }}$ conditions than in the shallow station control (450) (Table 2). No change in PSU density accompanied the large increase in PSU-O $\mathrm{O}_{2}$ size in shortened $\mathrm{H}_{\text {sat }}$ plants, but the lengthened $\mathrm{H}_{\text {sat }}$ plants had a 2-fold 
reduction in PSU density accompaning the doubling in PSU- $\mathrm{O}_{2}$ size. These changes in $\mathrm{PSU}-\mathrm{O}_{2}$ sizes and PSU densities can account for both the doubled leaf chlorophyll content in the shortened $\mathrm{H}_{\text {sat }}$ treatment, and the lack of change in chlorophyll in the lengthened $\mathrm{H}_{\text {sal }}$ treatment.

The photosynthetic responses to the deep station treatments in June were very different from those observed at the shallow station. Instead of an increase in $\mathrm{P}_{\max }$ under shortened $\mathrm{H}_{\text {sat }}$ conditions as at the shallow station, deep station plants showed a 30 to $40 \%$ reduction in $\mathrm{P}_{\max }$ on both a leaf area and chlorophyll basis in shortened $\mathrm{H}_{\text {sat }}$ conditions (Fig. 2b, d). This significantly $(p<0.05)$ reduced $P_{\max }$ was not related to changes in leaf chlorophyll content (Table 2), but the extremely large PSU- $\mathrm{O}_{2}$ size (1330) and decreased PSU density $\left(2.4 \mathrm{nmol}\right.$ PSU- $\mathrm{O}_{2} \mathrm{dm}^{-2}$ ) in the shortened $\mathrm{H}_{\text {sat }}$ plants compared with controls (PSU size $=820$ and PSU density $=4.6 \mathrm{nmol}$ PSU $-\mathrm{O}_{2} \mathrm{dm}^{-2}$ ) could account for the reduced photosynthetic performance. The lengthened $\mathrm{H}_{\text {sat }}$ plants from the deep station showed no change in P-I or PSU characteristics in comparison to controls, with the exception of $\mathrm{P}_{\max } \mathrm{dm}^{-2}$ which was reduced by $27 \%$ compared to the control. Leaf chlorophyll content was higher $\left(3.2 \mathrm{mg} \mathrm{chl} \mathrm{dm}{ }^{-2}\right)$ in deep station controls than at the shallow station $(2.4$

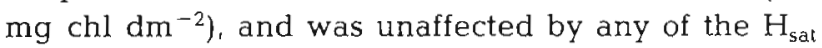
manipulations.

\section{Biomass characteristics}

Shortened $\mathrm{H}_{\text {sat }}$ conditions caused large reductions $(50 \%)$ in leaf biomass $\left(\mathrm{g} \mathrm{m}^{-2}\right)$ at both shallow and deep stations. Specific leaf area $\left(\mathrm{dm}^{2} \mathrm{~g}^{-1}\right)$ increased
$40 \%$ under shortened $\mathrm{H}_{\text {sat }}$ at both stations. The lengthened $\mathrm{H}_{\text {sat }}$ did not affect shoot size, leaf biomass, or specific leaf area at either station.

The recovery of leaf biomass after a $30 \mathrm{~d}$ period of shortened $\mathrm{H}_{\text {sat }}$ conditions at both stations was monitored through the remainder of the growing season. At the shallow station, the $3 \mathrm{~m}^{2}$ plots were indistinguishable from the surrounding canopy within about $14 \mathrm{~d}$. However, at the deep station, no living eelgrass shoots were found several weeks after the completion of the experiments and for the remainder of the season. This treatment site was left undisturbed, yet the plants were unable to recover from the effects of the $30 \mathrm{~d}$ shortened $\mathrm{H}_{\text {sat }}$ conditions.

\section{Growth characteristics}

Eelgrass shoots at both shallow and deep station grew at equivalent rates based on relative leaf production (Table 2). Shortened $\mathrm{H}_{\text {sat }}$ led to a $25 \%$ reduction in relative leaf production rates at both stations. Leaf production rates $\mathrm{m}^{-2}$ were reduced by $50 \%$ at the shallow station under shortened $\mathrm{H}_{\text {sat }}$, while leaf formation rates were unaffected. At the deep station, leaf formation time was increased to $35 \mathrm{~d}$ in the shortened $\mathrm{H}_{\text {sat }}$ compared to $19 \mathrm{~d}$ in the control. The lengthened $\mathrm{H}_{\text {sat }}$ had no effect on growth at either station.

\section{Daily carbon balance}

At the shallow station in June, effective adjustment of photosynthetic rate by the lengthened and shor-

Table 3. Zostera marina. Daily carbon balance of leaf tissue from June and August experiments

\begin{tabular}{|c|c|c|c|c|c|c|}
\hline \multirow[t]{2}{*}{ Parameter } & \multicolumn{3}{|c|}{ Shallow station } & \multicolumn{3}{|c|}{ Deep station } \\
\hline & $\begin{array}{l}\text { Lengthened } \\
\qquad \mathrm{H}_{\text {sat }}\end{array}$ & Control & $\begin{array}{c}\text { Shortened } \\
\mathrm{H}_{\text {sat }}\end{array}$ & $\begin{array}{c}\text { Lengthened } \\
\mathrm{H}_{\text {sat }}\end{array}$ & Control & $\begin{array}{c}\text { Shortened } \\
\mathrm{H}_{\text {sat }}\end{array}$ \\
\hline \multicolumn{7}{|l|}{ June experiments } \\
\hline $\begin{array}{l}\text { Gross daily photosynthesis } \\
\operatorname{mg} \mathrm{Cg}(\mathrm{dry})^{-1} \mathrm{~d}^{-1}\end{array}$ & 15.6 & 18.5 & 30.2 & 13.3 & 12.8 & 8.6 \\
\hline Daily respiration & & & & & & \\
\hline $\operatorname{mg} C g(d r y)^{-1} d^{-1}$ & -4.7 & -6.3 & -11.7 & -4.0 & -6.6 & -8.6 \\
\hline $\begin{array}{l}\text { Net daily photosynthesis } \\
\operatorname{mg} \mathrm{Cg}(\mathrm{dry})^{-1} \mathrm{~d}^{-1}\end{array}$ & 10.9 & 12.2 & 18.5 & 9.3 & 6.2 & 0.0 \\
\hline August experiments & & & & & & \\
\hline $\begin{array}{l}\text { Gross daily photosynthesis } \\
\text { mg Cg(dry })^{-1} d^{-1}\end{array}$ & 19.6 & 14.0 & 12.9 & 16.3 & 10.2 & 14.6 \\
\hline $\begin{array}{l}\text { Daily respiration } \\
\text { mg C }(\text { dry })^{-1} d^{-1}\end{array}$ & -5.1 & -6.1 & -9.6 & -3.3 & -5.1 & -10.4 \\
\hline $\begin{array}{l}\text { Net daily photosynthesis } \\
\text { mg } C g(d r y)^{-1} d^{-1}\end{array}$ & 14.5 & 7.9 & 3.3 & 12.8 & 5.1 & 4.2 \\
\hline
\end{tabular}


tened $\mathrm{H}_{\text {sat }}$ plants resulted in net carbon gain $(+10.9$ and $+18.5 \mathrm{mg} \mathrm{C} \mathrm{g}^{-1} \mathrm{~d}^{-1}$ ) (Table 3). Net carbon gain was also calculated for control plants $\left(+12.2 \mathrm{mg} \mathrm{C} \mathrm{g}^{-1}\right.$ $\mathrm{d}^{-1}$ ). At the deep station, net daily photosynthesis was $+9.3 \mathrm{mg} \mathrm{C} \mathrm{g}^{-1} \mathrm{~d}^{-1}$ for lengthened $\mathrm{H}_{\text {sat }}$ and $+6.2 \mathrm{mg} \mathrm{C}$ $\mathrm{g}^{-1} \mathrm{~d}^{-1}$ for control plants; however, no net carbon gain was obtained for shortened $\mathrm{H}_{\text {sat }}$ leaf tissue $(0.0 \mathrm{mg} \mathrm{C}$ $\left.\mathrm{g}^{-1} \mathrm{~d}^{-1}\right)$. The differences in daily carbon balance under the different $\mathrm{H}_{\text {sat }}$ conditions were attributable to changes in gross photosynthesis, respiration and $\mathrm{H}_{\text {sat }}$.

\section{August experiments}

\section{Photosynthetic characteristics}

Photosynthetic characteristics at both shallow and deep stations in August were less responsive to $H_{\text {sat }}$ manipulations than in June (Fig. 3, Table 4). The average $\alpha$ of the P-I curves was $4.3 \mathrm{nmol} \mathrm{O}_{2} \mathrm{mg} \mathrm{chl}^{-1}$ $\mathrm{min}^{-1} / \mu \mathrm{E} \mathrm{m}^{-2} \mathrm{~s}^{-1}$, with no significant $(\mathrm{p}<0.05)$ differences between stations or treatments. Dark respiration rates per chlorophyll were $0.10 \mu \mathrm{mol} \mathrm{O} \mathrm{O}_{2} \mathrm{mg} \mathrm{chl}^{-1}$ $\min ^{-1}$ and not significantly different $(p<0.05)$ between stations or in any of the treatments. At the shallow station, $\mathrm{P}_{\max } \mathrm{dm}^{-2}$ was increased (20\%) under lengthened $\mathrm{H}_{\text {sat }}$ conditions compared to controls. However, no change in $\mathrm{P}_{\max }$ per chlorophyll was observed. The changes in photosynthetic rate $\mathrm{dm}^{-2}$ were not accompanied by any significant changes in leaf chlorophyll content, chlorophyll a/b ratios, or $\mathrm{PSU}-\mathrm{O}_{2}$ sizes (Table 4). An increase in PSU-O $\mathrm{O}_{2}$ density was observed in shortened $\mathrm{H}_{\text {sat }}$ plants at the deep station compared to controls. This $60 \%$ increase in PSU density corresponded to a $55 \%$ increase in $\mathrm{P}_{\max } \mathrm{dm}^{-2}$, and probably accounted for the increased photosynthetic performance under these conditions.

\section{Biomass characteristics}

At the shallow station, no significant changes in shoot size or leaf biomass were observed under either lengthened or shortened $\mathrm{H}_{\text {sat }}$ treatments (Table 4). Specific leaf area decreased in lengthened $\mathrm{H}_{\text {sat }}$ and increased in shortened $\mathrm{H}_{\text {sat }}$ periods by about $10 \%$ in both cases.

At the deep station, leaf biomass $\mathrm{m}^{-2}$ increased by $70 \%$ in the lengthened $\mathrm{H}_{\text {sat }}$ and was roughly halved in the shortened $\mathrm{H}_{\text {sat }}$ compared to controls. Shoot size was unaffected, while specific leaf area was slightly decreased $(6 \%)$ in lengthened $\mathrm{H}_{\text {sat }}$ and increased
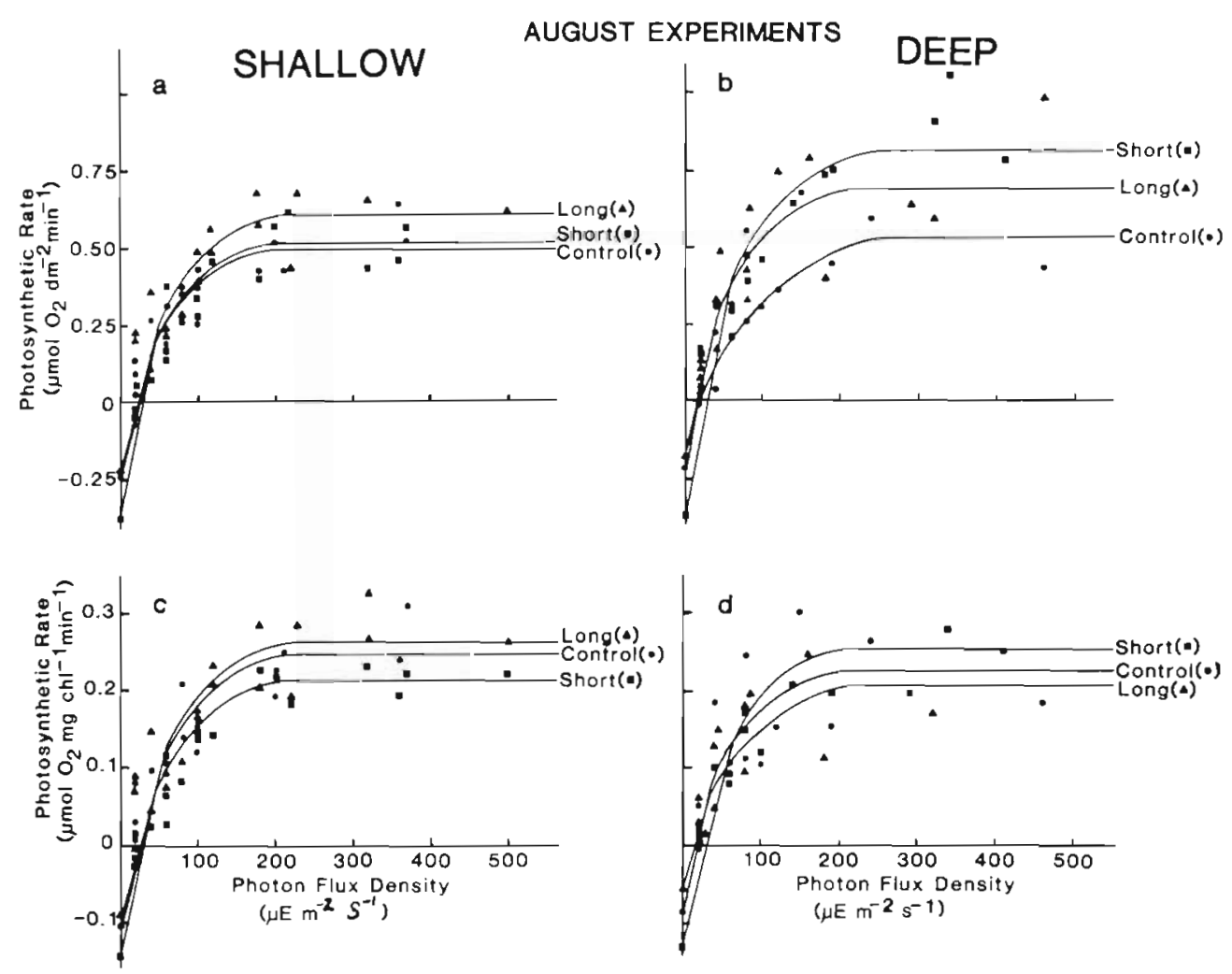

Fig. 3. Zostera marina. Photosynthesis-irradiance curves for shallow and deep station. Leaf tissue collected from control, lengthened (long) and shortened (short) daily light period sites at the completion of August experiments. Net photosynthesis expressed as a function of leaf area $(a, b)$ and as a function of chlorophyll $(c, d)$ 
Table 4. August experiments. Photosynthetic, biomass and growth parameters of Zostera marina for control and manipulation sites at shallow and deep stations

\begin{tabular}{|c|c|c|c|c|c|c|}
\hline \multirow[t]{2}{*}{ Parameter } & \multicolumn{3}{|c|}{ Shallow station } & \multicolumn{3}{|c|}{ Deep station } \\
\hline & $\begin{array}{l}\text { Lengthened } \\
\mathrm{H}_{\text {sat }}\end{array}$ & Control & $\begin{array}{c}\text { Shortened } \\
\mathrm{H}_{\text {sat }}\end{array}$ & $\begin{array}{l}\text { Lengthened } \\
\mathrm{H}_{\mathrm{sat}}\end{array}$ & Control & $\begin{array}{c}\text { Shortened } \\
\mathrm{H}_{\text {sat }}\end{array}$ \\
\hline $\begin{array}{l}\mathrm{P}_{\max } \text { (net) } \\
\quad \mu \mathrm{mol} \mathrm{O} \mathrm{O}_{2} \mathrm{dm}^{-2} \mathrm{~min}^{-1} \\
\quad \mu \mathrm{mol} \mathrm{O} \mathrm{O}_{2} \mathrm{mg} \mathrm{chl}^{-1} \mathrm{~min}^{-1}\end{array}$ & $\begin{array}{l}0.60^{\mathrm{a}} \\
0.26^{\mathrm{a}}\end{array}$ & $\begin{array}{l}0.50^{\mathrm{b}} \\
0.25^{\AA}\end{array}$ & $\begin{array}{l}0.51^{\mathrm{b}} \\
0.22^{\mathrm{a}}\end{array}$ & $\begin{array}{l}0.69^{\mathrm{c}} \\
0.21^{\mathrm{a}}\end{array}$ & $\begin{array}{l}0.53^{\mathrm{b}} \\
0.23^{\mathrm{a}}\end{array}$ & $\begin{array}{l}0.82^{\mathrm{c}} \\
0.26^{\mathrm{a}}\end{array}$ \\
\hline $\begin{array}{l}\text { Leaf chlorophyll content } \\
\text { mg chl dm-2 } \\
\text { chlorophyll } a / b\end{array}$ & $\begin{array}{l}2.5^{\mathrm{a}} \\
2.5^{\mathrm{a}}\end{array}$ & $\begin{array}{l}2.5^{\mathrm{a}} \\
2.7^{\mathrm{a}}\end{array}$ & $\begin{array}{l}2.5^{\mathrm{a}} \\
2.3^{\mathrm{a}}\end{array}$ & $\begin{array}{l}2.9^{\mathrm{a}} \\
2.6^{\mathrm{a}}\end{array}$ & $\begin{array}{l}2.5^{\mathrm{a}} \\
2.6^{\mathrm{a}}\end{array}$ & $\begin{array}{l}2.9^{\mathrm{a}} \\
2.5^{\mathrm{a}}\end{array}$ \\
\hline $\begin{array}{l}\text { Photosynthetic unit size } \\
\text { PSU }-\mathrm{O}_{2}\end{array}$ & $580^{\mathrm{a}}$ & $530^{\alpha}$ & $570^{\mathrm{a}}$ & $650^{\mathrm{a}}$ & $560^{\mathrm{a}}$ & $690^{\mathrm{a}}$ \\
\hline $\begin{array}{l}\text { Photosynthetic unit density } \\
\mathrm{n} \text { mol PSU- } \mathrm{O}_{2} \mathrm{dm}^{-2}\end{array}$ & $4.8^{\mathrm{a}}$ & $5.2^{\mathrm{a}}$ & $4.3^{\mathrm{a}}$ & $5.4^{\mathrm{a}}$ & $5.2^{\mathrm{a}}$ & $5.6^{a}$ \\
\hline $\begin{array}{l}\text { Shoot size } \\
\text { g (dry) shoot }{ }^{-1}\end{array}$ & $0.52^{\mathrm{a}}$ & $0.54^{\mathrm{d}}$ & $0.56^{\mathrm{a}}$ & $0.71^{\mathrm{a}}$ & $0.52^{\mathrm{a}}$ & $0.56^{\mathrm{a}}$ \\
\hline $\begin{array}{l}\text { Leaf biomass } \\
\qquad \mathrm{g}(\mathrm{dry}) \mathrm{m}^{-2}\end{array}$ & $410^{a}$ & $370^{\mathrm{a}}$ & $330^{\mathrm{a}}$ & $215^{\mathrm{b}}$ & $125^{c}$ & $60^{\mathrm{d}}$ \\
\hline $\begin{array}{l}\text { Specific leaf area } \\
\text { (leaf tissue produced during } \\
\text { experiments) } \mathrm{dm}^{2} \mathrm{~g}(\mathrm{dry})^{-1}\end{array}$ & $1.7^{\mathrm{a}}$ & $1.9^{b}$ & $2.1^{\mathrm{c}}$ & $1.6^{\mathrm{d}}$ & $1.7^{\mathrm{a}}$ & $2.0^{c}$ \\
\hline $\begin{array}{l}\text { Relative leaf production rate } \\
\text { mg (dry) } g(d r y)^{-1} d^{-1}\end{array}$ & $13^{a}$ & $15^{\mathrm{a}}$ & $15^{a}$ & $17^{a}$ & $16^{\mathrm{a}}$ & $15^{\mathrm{a}}$ \\
\hline $\begin{array}{l}\text { Leaf production rate } \\
g\left(\text { dry } \mathrm{m}^{-2} \mathrm{~d}^{-1}\right.\end{array}$ & $6.6^{\mathrm{a}}$ & $6.3^{\mathrm{a}}$ & $5.9^{\mathrm{a}}$ & $2.6^{b}$ & $1.8^{\complement}$ & $1.0^{\mathrm{d}}$ \\
\hline $\begin{array}{l}\text { Leaf formation rate } \\
\text { d }\end{array}$ & $20^{a}$ & $17^{\mathrm{a}}$ & $23^{b}$ & $12^{c}$ & $28^{\mathrm{b}}$ & $41^{\mathrm{d}}$ \\
\hline
\end{tabular}

(18\%) in shortened $\mathrm{H}_{\text {sat }}$. As observed in June, the deep station plants subjected to shortened $H_{\text {sat }}$ were unable to recover from this treatment, and no living shoots were observed until the following spring at this site.

\section{Growth characteristics}

At the shallow station, no significant $(\mathrm{p}<0.05)$ changes in relative leaf production or leaf production $\mathrm{m}^{-2}$ were observed (Table 4). Leaf formation time increased in shortened $\mathrm{H}_{\text {sat }}$ conditions (23 d) relative to the control $(17 \mathrm{~d})$. At the deep station, relative leaf production rates were similar to shallow station values and unaffected by the manipulations. However, both production rates $\mathrm{m}^{-2}$ and leaf formation rates were strongly affected by the manipulations. Leaf production $\mathrm{m}^{-2}$ was increased by $44 \%$ in lengthened $\mathrm{H}_{\text {sat }}$ relative to controls with more rapid leaf formation (12 d) compared to controls $(28 \mathrm{~d})$. In the shortened $\mathrm{H}_{\text {sat }}$ leaf production $\mathrm{m}^{-2}$ decreased ( $44 \%$ ) relative to controls and leaf formation times increased from 28 to $41 \mathrm{~d}$.

\section{Daily carbon balance}

At the shallow station in August, gross daily photosynthesis increased and daily respiration decreased with lengthening of $\mathrm{H}_{\text {sat }}$ (Table 3). This resulted in a trend of increasing daily photosynthesis with increasing $\mathrm{H}_{\text {sat }}$ in shortened $\left(+3.3 \mathrm{mg} \mathrm{C} \mathrm{g} \mathrm{C}^{-1} \mathrm{~d}^{-1}\right)$, control $\left(+7.9 \mathrm{mg} \mathrm{C} \mathrm{g}^{-1} \mathrm{~d}^{-1}\right)$ and lengthened (+14.5 $\mathrm{mg} \mathrm{C}$ $\left.\mathrm{g}^{-1} \mathrm{~d}^{-1}\right) \mathrm{H}_{\text {sat. }}$. At the deep station, a similar trend was observed in daily net photosynthesis with increasing photosynthesis in longer $\mathrm{H}_{\text {sat }}$ periods: shortened, $+4.2 \mathrm{mg} \mathrm{C} \mathrm{g}^{-1} \mathrm{~d}^{-1}$; control, $+5.1 \mathrm{mg} \mathrm{C} \mathrm{g}^{-1} \mathrm{~d}^{-1}$; lengthened, $+12.8 \mathrm{mg} \mathrm{C} \mathrm{g} \mathrm{g}^{-1}$.

\section{DISCUSSION}

The hypothesis that light environment controls the depth distribution, photosynthesis and productivity of eelgrass growing along a natural depth gradient was tested with in situ manipulations of light intensity (Dennison \& Alberte 1982) and daily light period (pre- 
sent study). Previous investigations in the same eelgrass bed revealed no growth responses to in situ manipulations of light intensity unless light intensity perturbation was accompanied by differences in daily light periods (Dennison \& Alberte 1982). Results of this earlier study can be compared to results of the present study to demonstrate that daily light periods are more important than absolute PPFD. The experiments were of different duration ( $30 \mathrm{~d}$ vs 7 to $14 \mathrm{~d}$ ) and conducted in different years, but the results of the deep station shade treatment provide a control for possible differences between experiments. Under the same shade treatment ( $-55 \%$ PPFD), eelgrass growth and photosynthesis responses were essentially identical in both experiments. For example, leaf formation times were decreased by the same proportion $(47 \%)$ in both studies, while photosynthetic capacities were unaffected. This consistency in growth responses to shading treatments in the 2 experiments accentuates the difference in eelgrass growth response to increased light intensities (Dennison \& Alberte 1982) and lengthened light periods (present study). Hence, the results of both sets of experiments can be used to conclude that $\mathrm{H}_{\text {sat }}$ rather than instantaneous PPFD is the important feature of light environment controlling eelgrass photosynthesis, growth and biomass. Indeed, previous studies of terrestrial plant response to light regime have also demonstrated that peak PPFDs per se have no significant effect on plant response (Chabot et al. 1979, Nobel 1983).

The results of $\mathrm{H}_{\text {sat }}$ manipulations can be summarized by plotting eelgrass growth rate as a function of $\mathrm{H}_{\text {sat }}$ (Fig. 4). Eelgrass growth rates (expressed in terms of leaf formation rates) show a saturation-type response. $H_{\text {sat }}$ values exceeding approximately $10 \mathrm{~h}$ do not appear to affect eelgrass growth rates. However, when

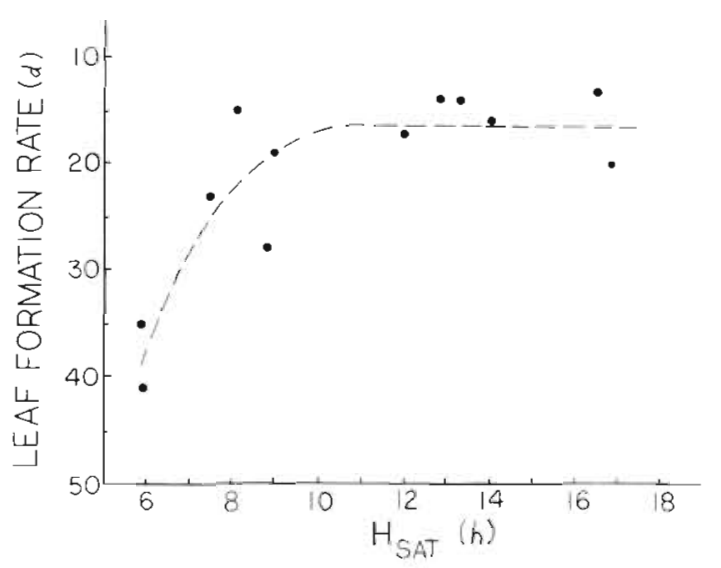

Fig. 4. Zostera marina. Leaf formation rates (from Tables 2 \& 4) plotted as a function of $H_{\text {sat }}$ values (from Table 1) from lengthened, control and shortened $\mathrm{H}_{\text {sat }}$ experiments in June and August. Curve fitted by eye
$\mathrm{H}_{\text {sat }}$ values fell below $10 \mathrm{~h}$, due to manipulations in light regime, eelgrass leaf growth rates were strongly affected. Ambient $\mathrm{H}_{\text {sat }}$ values at the deep station were roughly $9 \mathrm{~h}$ (see Table 1), below the saturation region. Growth appears to be a direct function of $\mathrm{H}_{\text {sat }}$ at the deep station, hence 'light-limited'

The $P_{\max }$ values were similar between $H_{\text {sat }}$ treatments when leaf chlorophyll and PSU characteristics were unaffected by the light regime manipulations (August). However, $\mathrm{P}_{\max }$ was not similar between $\mathrm{H}_{\text {sar }}$ treatments when leaf chlorophyll and PSU characteristics were altered by light regime (June). Decreases in PSU density corresponded to lower $P_{\max }$ values, although increases in PSU density did not always correspond to greater photosynthetic performance (shortened $\mathrm{H}_{\text {sat }}$ conditions at the shallow station in June).

The daily carbon balance of Zostera marina leaf tissue under different $\mathrm{H}_{\text {sat }}$ conditions provides an accurate predictor of long-term plant survival. The deep station shortened $\mathrm{H}_{\text {sat }}$ conditions $\left(\mathrm{H}_{\text {sat }}<6 \mathrm{~h}\right.$ ) led to the lowest observed daily net carbon gains, where plant mortality following the $30 \mathrm{~d}$ experiments was observed. These findings indicate that eelgrass in the deep portions of the meadow (5 to $6 \mathrm{~m}$ ) is living at or near the minimum $\mathrm{H}_{\text {sat }}(<6 \mathrm{~h})$ for growth and survival. Daily carbon balances of deep station leaf tissue indicate lower net carbon gains than shallow station leaf tissue, suggesting that daily carbon balances are related to plant growth rates (cf. Drew 1978). For example, large net carbon gains calculated for leaf tissue corresponded to rapid leaf formation rates.

In June, the manipulations affected not only growth and biomass, but also photosynthetic features at both stations (Table 2). In all cases, as reported previously (Dennison \& Alberte 1982), specific leaf area and leaf formation times were the most responsive growth or biomass parameters to light manipulations. Studies on terrestrial plants showed similar decreases in specific leaf area in response to shortened daily light periods (Chatterton \& Silvius 1980) and increases in response to lengthened daily light periods (Chabot et al. 1979).

The capacity for photosynthetic adjustment by Zostera marina in response to $\mathrm{H}_{\text {sat }}$ was demonstrated by changes in P-I relationships and PSU characteristics. These apparently adaptive molecular and cellular level adjustments occurred only early in the growing season (June), and suggest that seasonal features of the eelgrass habitat may influence photosynthetic adjustment to light environment. Water temperature at the study site was highly variable seasonally and could affect photosynthetic adaptive capacity. In the present study, water column temperature was $20^{\circ} \mathrm{C}$ at the completion of both June and August experiments, and this same temperature was used for the photosynthesis measurements. However, water column temperatures 
did vary during the $30 \mathrm{~d}$ experiments, ranging from 14 to $20^{\circ} \mathrm{C}$ in June and 19 to $22^{\circ} \mathrm{C}$ in August. The mean water temperature was $15^{\circ} \mathrm{C}$ in June and $21^{\circ} \mathrm{C}$ in August, with 1 day in June and 27 days in August in which water temperature was $20^{\circ} \mathrm{C}$ or above. $P_{\max }$ and dark respiration rates are highly temperature sensitive in Z. marina (Evans 1983, Marsh et al. 1983) and in related seagrass species (Bulthius 1983). In addition, when eelgrass is grown at higher than ambient temperatures, some of the phenotypic adaptive plasticity may be lost (Evans 1983). This reduced adaptive capacity may account for the lack of photosynthetic adjustments in the August experiments with the warmer water temperatures.

The physiological status of the leaf tissue in June and August could be quite different due to phenological differences in the eelgrass population, despite the fact that all photosynthetic measurements were conducted with leaf tissue which emerged from the bundle sheath approximately $15 \mathrm{~d}$ prior to analysis. In June, the eelgrass meadow was characterized by a developing leaf canopy, rapid leaf formation ( $2 \mathrm{wk}$ ) and many flowering shoots. In August, the leaf canopy was fully developed, leaf formation slower ( 2 to $4 \mathrm{wk}$ ), with many shoots senescing. The phenology of eelgrass vegetative growth and flowering has been documented (e.g. Sand-Jensen 1975, Aioi 1980, Phillips et al. 1983), but the influence of seasonality on eelgrass physiological parameters has not been addressed. In crop plants, losses in the capacity of photosynthetic responses have been observed during flowering and senescence (Leith 1974).

The effects of water depth on daily light periods were quite dramatic at the Great Harbor study site. Similar effects on $\mathrm{H}_{\text {sat }}$ regimes could be brought about by latitudinal differences in light regime. For example, daily light periods are longer at higher latitudes during summer, especially near the summer solstice, which could account for the high summer productivity observed in high latitude eelgrass beds (e.g. McRoy \& McMillan 1977). As such, $H_{\text {sat }}$ regimes may be an important factor in the global productivity and distribution of this and other seagrass species (cf. Aioi 1980). Simulation models of Zostera marina production and biomass have been employed and indicate light regime to be of primary importance in deep-growing eelgrass (Short 1980, Verhagen \& Nienhuis 1983).

In the Woods Hole region, and in areas throughout its distributional range, Zostera marina grows along a natural depth gradient. This depth distribution results in dramatic PPFD gradients from the shallow to deep portions of eelgrass beds. Accompanying the reductions in PPFD, there is a shortening in the daily periods of saturated photosynthesis, or $\mathrm{H}_{\text {sat }}$, with increasing water depth. For example, in the present examination
$\mathrm{H}_{\text {sat }}$ was $3 \mathrm{~h}$ longer at the shallow station $(12 \mathrm{~h})$ than at the deep station $(9 \mathrm{~h})$. The hypothesis that these $\mathrm{H}_{\text {sat }}$ regimes control the depth distribution, photosynthesis and productivity of eelgrass growing along a natural depth gradient was tested with in situ $\mathrm{H}_{\text {sat }}$ manipulations. It is concluded that the growth and biomass of eelgrass growing near the maximum water depth penetration of eelgrass is controlled primarily by light environment, and specifically by the daily period of saturating PPFD $\left(\mathrm{H}_{\text {sat }}\right)$.

Acknowledgements. R. Gilbert, C. Johnson, R. Smith and C. Tynan assisted in field work. T. Rioux contributed invaluable logistical assistance with the diving program. B. Gunning, B. Whittaker and $J$. Liberman provided access and expertise necessary for underwater lighting. Dr. Richard Payne made numerous light measurements for the development of conversion factors. The Eppley Laboratories (Newport, RI), supplied light data used in this study. Discussions with Drs R. Aller and J. Marsh were very helpful, along with editorial assistance from 2 anonymous reviewers. Laboratory space during the field season was provided by Dr. Ivan Valiela and the Marine Ecology course at the Marine Biological Laboratory, Woods Hole, MA. W. C. Dennison was supported by NH Training Grant (GM07183), and research was supported by NSF Grant OCE 82-14914.

\section{LITERATURE CITED}

Aioi, K. (1980). Seasonal change in the standing crop of eelgrasss (Zostera marina L.) in Odawa Bay, central Japan. Aquat. Bot. 8: 343-354

Alberte, R. S., McClure, P. R., Thornber, J. P. (1976). Photosynthesis in trees: organization of chlorophyll and photosynthetic unit size in isolated gymnosperm chloroplasts. Pl. Physiol, Wash. 59: 351-353

Arnon, D. 1. (1949). Copper enzymes in isolated chloroplasts. Polyphenoloxidase in Beta vulgaris. Pl. Physiol. 24: 1-15

Backman, T. W., Barilotti, D. C. (1976). Irradiance reduction: effects on standing crops of the eelgrass, Zostera marina, in a coastal lagoon. Mar. Biol. 34: 33-40

Bulthius, D. A. (1983). Effects of temperature on the photosynthesis-irradiance curve of the Australian seagrass, Heterozostera tasmanica. Mar. Biol. Lett. 4: 47-57

Burkholder, P. R., Doheny, T. E. (1968). The biology of eelgrass. Contr. No. 3, Dept. Conserv. and Waterways, Town Hempstead, New York

Chabot, B. F., Jurik, T. W., Chabot, J. F. (1979). Influence of instantaneous and integrated light-flux density on leaf anatomy and photosynthesis. Am. J. Bot. 66: 940-945

Chatterton, N. J., Silvius, J. E. (1980). Acclimation of photosynthate partitioning and photosynthetic rates to changes in length of the daily photosynthetic period. Ann. Bot. 46: $739-745$

Dennison, W C., Alberte, R. S. (1982). Photosynthetic responses of Zostera marina L. (eelgrass) to in situ manipulations of light intensity. Oecologia 55: 137-144

Drew, E. A. (1978). Factors affecting photosynthesis and its seasonal variation in the seagrass Cymodocea nodosa (Urcria) Ashers. and Posidonia oceanica (L.) Delile in the Mediterranean. J. exp. mar. Biol. Ecol. 31. 173-194

Evans, A. S. (1983). Growth and photosynthetic responses to 
temperature of two populations of Zostera marina. Biol. Bull. mar. biol. Lab., Woods Hole 165: 508

Kursar, T. K., Alberte, R. S. (1983). Photosynthetic unit organization in a red alga: Relationships between light-harvesting pigments and reaction centers. Pl. Physiol., Wash. 72: 409-414

Leith, H. (ed.) (1974). Phenology and seasonality modeling. Springer-Verlag, Berlin

Marsh, J. A., Dennison, W. C., Alberte, R. S. (1983). Photosynthesis as a function to temperature in eelgrass (Zostera marina L.). EOS Trans. Am. Geophys. Un. 64: 1057

Mazzella, L., Mauzerall, D., Lyman, H., Alberte, R. S. (1981). Protoplast isolation and photosynthetic characteristics of Zostera marina L. (eelgrass). Botanica mar. 24: 285-290

McRoy, C. P., McMillan, C. (1977). Production ecology and physiology of seagrasses. In: McRoy, C. P., Helfferich, C. (ed.) Seagrass ecosystems: a scientific perspective. Marcel Dekker, New York, p. 53-87

Mishkind, D. T., Mauzerall, D. (1980). Kinetic evidence for a common photosynthetic step in diverse seaweeds. Mar Biol. 56: 261-265
Nobel, P. (1983). Biophysical plant physiology and ecology W. H. Freeman, San Francisco

Phillips, R. C., Grant, W. S., McRoy, C. P. (1983). Reproductive strategies of eelgrass (Zostera marina L.). Aquat. Bot. 16: $1-20$

Sand-Jensen, K. (1975). Biomass, net production and growth dynamics in an eelgrass (Zostera marina L.) population in Vellerup Vig, Denmark. Ophelia 14: 185-201

Short, F. T. (1980). A simulation model of the seagrass production system. In: Phillips, R. C., McRoy, C. P. (ed.) Handbook of seagrass biology: a ecosystem perspective. Garland, New York, p. 277-296

Verhagen, J. H. G., Nienhuis, P. H. (1983). A simulation model of production, seasonal changes in biomass and distribution of eelgrass (Zostera marina) in Lake Grevelingen. Mar. Ecol. Prog. Ser. 10: 187-195

Wiginton, J. R., McMillan, C. (1979). Chlorophyll composition under control light conditions as related to the distribution of seagrasses in Texas and the U. S. Virgin Islands. Aquat. Bot. 6: 171-184

This paper was presented by Dr. G. W. Thayer; it was accepted for printing on May 17, 1985 